\title{
Lateral
}

Journal of the Cultural Studies Association

\section{Review of Prison Land: Mapping Carceral Power Across Neoliberal America by Brett Story (University of Minnesota Press)}

by Marcia Klotz | Book Reviews, Issue 9.1 (Spring 2020)

ABSTRACT Brett Story's Prison Land: Mapping Carceral Power Across Neoliberal America offers a timely reflection on the role of mass incarceration in remaking the neoliberal contours of contemporary U.S. culture. Working within the traditions of critical prison studies and structural critiques of neoliberalism, Story offers detailed portraits of a number of landscapes shaped by the logic of mass incarceration. She persuasively argues that the work of prison abolitionism must also encompass the deeper structural projects of abolishing racism and other injustices in society at large. This book is best read alongside the documentary, The Prison in Twelve Landscapes (2016), by the same author.

KEYWORDS abolitionism, neoliberalism, prison studies, United States

Prison Land: Mapping Carceral Power across Neoliberal America. By Brett Story. Minneapolis, Minnesota, USA; London, UK: University of Minnesota Press, 2019, 219 pp. ISBN 9788-1-5179-0688-7, paperback. US List: \$19.95.

As a trained geographer, Brett Story has written a book about how mass incarceration remakes space in the United States. It's not about the space of the prison per se, but rather, all of the other spaces around it and to which it is linked, through contiguous economies, flows of bodies, and disciplinary modes of logic. Prison Land works like a giant jigsaw puzzle that is only two-thirds complete, with the main focus of the image-the prison towers in the middle of the frame-still unfinished. Rather than discussing the world inside the prison itself, the reader is treated to a series of brilliantly drawn and carefully chosen vignettes that illustrate how mass incarceration remakes its world. By the end of the book, we start to see the language and the logic of the prison everywhere-in the surveillance apparatus at the workplace, in educational spaces and parks, in community centers and churches. Mass incarceration corrupts the very air we breathe under neoliberalism in the United States. If we are to devote ourselves to the hard work of abolitionism - and Story tirelessly and unflinchingly challenges us to do so- that project will not stop at the prison gates.

The first two chapters focus on gentrification. One treats the skyrocketing values of office space in downtown Detroit, where the devastation wrought by the mortgage scams of 2007-2009 have resulted in massive foreclosures. Story documents the efforts that went into constructing urban spaces as "blighted" and "abandoned" in order to make them available for the profitable development of skyscraper office complexes and urban hipster markets. That work includes governmental policies (e.g., cutting off drinking water from 
homes, defunding schools, etc.), "broken-windows" policing strategies, and

"revitalization" funds used to raze condemned properties. Chapter 2 focuses on the use of "urban frontier" discourse in Brownsville, a Brooklyn neighborhood facing gentrification, in order to constitute residents as disposable, hence dispossessable. Here the first section of interlocking puzzle pieces begins to emerge: those prison walls cannot be taken down without simultaneously attacking the "accumulation by dispossession" strategies that make gentrification possible.

But prison land, the terrain remade by incarceration regimes, takes other forms as well. The third chapter focuses on coal country in Appalachia, a region where mountaintop removal has destroyed soil productivity and poisoned water sources. In desperately poor regions like these, prisons offer the only employment opportunities for local communities. Story interviews a number of local residents, whose hopes for new prison construction revolve around promised jobs, not a punitive ideology toward "criminals." Carceral logic emerges here as a consequence of decades of environmental degradation by an industry that has ruthlessly exploited both land and people. Story's point here is that a politics of punishment follows the impoverishment that recasts prison economies as a last-ditch, messianic hope; it does not lead the way.

The fourth vignette moves to an ungrounded, moving space: the bus that takes family members-mostly women and children-back and forth from New York City to Attica. Story describes the interior of this bus as a secondary kind of carceral space, where the connection and love that binds family and friends to those living in cages becomes a mode of punishment, stretching those who are already overextended (financially, emotionally, and physically) to the breaking point.

In later chapters, Story discusses how strategies of surveillance and behavioral control bleed outward from the prison to contaminate and remake the spaces outside. She takes issue here with many of the strategies touted by liberals who want to reduce the prison population by releasing - though still surveilling - those individuals deemed "nonthreatening" to the public through policies she decries as "transcarceration" strategies. One example is a "youth court," justified as an alternative to prison, that subjects young racialized people to the same kinds of censure and control they might experience insidebut now in a "community-based" format. Many reentry programs follow a similar logic. Such measures, which Story (quoting Ruth Wilson Gilmore, with whose work she is constantly in dialogue) calls "nonreformist reform," ultimately recriminalize those newly released, extending the prison space ever outward until it seems that no part of the world lies beyond its reach. Story argues that such programs focus on the personal responsibility or shortcomings of the individual, rather than interrogating the structural injustices that gave rise to the demand for incarceration in the first place.

This is where her book gave me pause. For those of us who volunteer in prisons or work with those recently released, I am not clear how Story's structural approach might be useful in our personal interactions with those attempting to make a meaningful life for themselves on the outside. The fault, we can say, is not yours, but lies with a society built around putting people in cages in the first place. While I am convinced that is true, it may offer little comfort to those for whom revolutionary change is not coming quickly enough.

That said, not only is Story an insightful geographer, theorist, and activist; she is also a gifted filmmaker. This book serves as a companion text to The Prison in Twelve Landscapes, a documentary thematizing many of the same issues, beautifully shot by 
photographer Maya Bankovic and released in 2016 (available through iTunes and Kanopy). The film is aesthetically ambitious, interweaving its narrative with lyrical, languid shots of coal trains and bus journeys, thereby locating the viewer in the sticky temporality of the dispossessed. The two texts are best read / viewed together. Both the film and the book showcase landscapes not represented in the other, but there is an elucidating overlap between them, too. Interviews with Detroit boosterists or poor Appalachian residents hoping for prison jobs are respectful, and Story's deep sympathy for those caught up in the system prevents simplistic vilification of those who stand to benefit from the making of prison land. The problem she identifies is structural, and the abolitionist politics for which she advocates must be, as well.

\title{
Author Information
}

\author{
Marcia Klotz \\ Marcia Klotz is an Assistant Professor of English and Gender \& Women's \\ Studies at the University of Arizona in Tucson. She is also director of the Prison \\ Education Project, which coordinates volunteers from the University of Arizona \\ and the local community to bring higher education classes to the Tucson State \\ Prison Complex. She is interested in the intersection of coercive power \\ structures and neoliberal economics, and is currently working on a book \\ manuscript titled Forgive Us Our Debts: Economic Theology in the Age of \\ Finance Capital.
}

View all of Marcia Klotz's articles.

\section{Article details}

Marcia Klotz, "Review of 'Prison Land: Mapping Carceral Power Across Neoliberal America' by Brett Story (University of Minnesota Press)," Lateral 9.1 (2020).

https://doi.org/10.25158/L9.1.15

This content is licensed under a Creative Commons Attribution 4.0 International License. Copyright is retained by authors.

Lateral is the peer-reviewed, open access journal of the Cultural Studies Association.

ISSN 2469-4053 